\title{
Chalk-Ex: Transport of Optically Active Particles from the Surface Mixed Layer
}

\author{
William M. Balch \\ Bigelow Laboratory for Ocean Sciences \\ McKown Point \\ W. Boothbay Harbor, ME 04575 \\ phone: (207) 633-9600 fax: (207)633-9641 email: bbalch@bigelow.org \\ Cynthia Pilskaln \\ Bigelow Laboratory for Ocean Sciences \\ McKown Point \\ W. Boothbay Harbor, ME 04575 \\ phone: (207) 633-9600 fax: (207)633-9641 email: cpilskaln@bigelow.org \\ Grant Number: N000140110042 \\ http://www.bigelow.org
}

\section{LONG-TERM GOALS}

To determine the mass balance of optically active particles within the surface boundary layer and to identify processes responsible for their redistribution.

\section{OBJECTIVES}

1) Perform manipulative experiments in which a known quantity of optically-active $\mathrm{CaCO}_{3}$ particles are introduced into the surface mixed layer, and tracked over time and space. This approach effectively removes uncertainty in the production term of the mass balance equation.

2) To quantify the relevant physical and biological loss terms that remove optically-active particles from the mixed layer (vertical mixing, sinking of discrete particles, particle aggregation, dissolution, and grazing-related repackaging of particles into fecal pellets).

\section{APPROACH}

This work has involved not only Balch and Pilskaln, but also Dr. A. Pleuddemann (WHOI; physical studies) and Drs. H. Dam and G. McManus (Univ. Connecticut; grazing/aggregation studies). Their work is not included in this report. Dr. J. Goes (Bigelow Laboratory; DOC analyses) was partially funded in this work as a post-doctoral investigator. For each of two cruises, our approach is to make two deployments of Cretaceous coccolith chalk. The first cruise was in November 2001. The second cruise is planned for Summer 2003. The purpose of the deployments is to study the fate of opticallyactive particles within the mixed layer (when the production term is known absolutely since we know precisely how much chalk we deploy). Our cruise plan in November involved deploying 13 tons of chalk in a patch in the surface mixed layer at a mesotrophic site, along the North American Continental Slope and a more eutrophic site within the Gulf of Maine. The rationale for this approach is that at the oligotrophic site, physics was expected to dominate biology in removing particles from the mixed 


\section{Report Documentation Page}

Form Approved

OMB No. 0704-0188

Public reporting burden for the collection of information is estimated to average 1 hour per response, including the time for reviewing instructions, searching existing data sources, gathering and maintaining the data needed, and completing and reviewing the collection of information. Send comments regarding this burden estimate or any other aspect of this collection of information,

including suggestions for reducing this burden, to Washington Headquarters Services, Directorate for Information Operations and Reports, 1215 Jefferson Davis Highway, Suite 1204, Arlington

VA 22202-4302. Respondents should be aware that notwithstanding any other provision of law, no person shall be subject to a penalty for failing to comply with a collection of information if it

does not display a currently valid OMB control number.

1. REPORT DATE

30 SEP 2002

2. REPORT TYPE

3. DATES COVERED

00-00-2002 to 00-00-2002

4. TITLE AND SUBTITLE

Chalk-Ex: Transport of Optically Active Particles from the Surface

Mixed Layer

6. AUTHOR(S)

5. CONTRACT NUMBER

5b. GRANT NUMBER

5c. PROGRAM ELEMENT NUMBER

5d. PROJECT NUMBER

5e. TASK NUMBER

5f. WORK UNIT NUMBER

7. PERFORMING ORGANIZATION NAME(S) AND ADDRESS(ES)

8. PERFORMING ORGANIZATION

REPORT NUMBER

Bigelow Laboratory for Ocean Sciences,,Laboratory for Ocean

Sciences,,W. Boothbay Harbor,,ME, 04575

9. SPONSORING/MONITORING AGENCY NAME(S) AND ADDRESS(ES)

10. SPONSOR/MONITOR'S ACRONYM(S)

11. SPONSOR/MONITOR'S REPORT

$\operatorname{NUMBER}(\mathrm{S})$

12. DISTRIBUTION/AVAILABILITY STATEMENT

Approved for public release; distribution unlimited

13. SUPPLEMENTARY NOTES

14. ABSTRACT

To determine the mass balance of optically active particles within the surface boundary layer and to identify processes responsible for their redistribution.

15. SUBJECT TERMS

16. SECURITY CLASSIFICATION OF:

a. REPORT

unclassified b. ABSTRACT

unclassified c. THIS PAGE

unclassified
17. LIMITATION OF ABSTRACT

Same as

Report (SAR)
18. NUMBER 19a. NAME OF

OF PAGES RESPONSIBLE PERSON

7 
layer. At the mesotrophic site, however, we expected easily detectable decreases in the mass of the mixed-layer patch associated with intense grazing activity (especially given expected grazing rates of 0.5-1 d $\mathrm{d}^{-1}$, and repackaging of this $\mathrm{CaCO}_{3}$ into fast-sinking fecal pellets).

\section{Patch deployment and surveys}

In the November '01 $r / v$ Endeavor cruise, a "pre-chalk" survey of the area was performed to assess background optical and physical properties. Then, chalk was diluted with surface seawater in a 1900L tank prior to being dispersed into the ship's wake through a stern-mounted spreader. Initial patch size was $\sim 1.5 \mathrm{~km}^{2}$. While one batch of the chalk/seawater slurry was being spread, the next was prepared in a second tank and spread when the first tank was empty. Each patch deployment took approximately $5 \mathrm{~h}$. By starting deployment just before dawn, the patch was deployed in time for the daytime overpasses of SeaWiFS and MODIS ocean color satellites (only possible for our Slope patch due to cloudy weather in the Gulf of Maine). Following the deployments of chalk, the following work was performed: deployment of drifting hydrographic arrays and sediment traps, surface optics surveys, vertical optics profiles, aerial surveys of the patch size and shape (using a towed balloon), and drifter tracking. Final recovery of traps and drifters occured 2-3 days after chalk deployment.

\section{Optical measurements- Balch}

Surface underway optical measurements of attenuation, absorption, scattering and backscattering were made during wagon-wheel and radiator surveys. Water-leaving radiance and downwelling irradiance (for calculating remote sensing reflectance) were measured from the bow of the $r / v$ Endeavor using a Satlantic SeaWiFS Aircraft Simulator (SAS). A towed, undulating Scan-Fish with Wet-Labs ECOVSF attached, allowed real-time mapping of the patch. High-resolution free-fall vertical profiles of spectral downwelling and upwelling radiance were made periodically using a Satlantic radiance profiler which allowed high-resolution estimation of diffuse attenuation coefficients. For vertical profile stations, discrete water samples were taken with a rosette sampler, at 6-8 depths within and below the mixed layer. Subsamples were filtered for suspended $\mathrm{CaCO}_{3}$ analyses (Fernández et al. 1993), plus the total and acid-labile backscattering of these samples was measured. The loss of backscattering following a lowering of the $\mathrm{pH}$ to 5.8, is well-correlated to the suspended calcite and allowed us to validate the laboratory calibration at sea.

\section{Sediment Trap Program and Particle Fluxes- Pilskaln}

In order to quantify the vertical export below the patch of Cretaceous chalk (due to biological and/or physical aggregation of the chalk particles), VERTEX-style MultiPIT drifting sediment traps (Knauer et al. 1979; Knap 1993) were deployed just below the base of the mixed layer within and outside each patch. MultiPIT trap "crosses" consisting of 8 collection tubes, were attached to a drifter mooring inside each patch. Outside the patch, we deployed a drifting sediment trap array with one MultiPIT trap cross located at the same depth as the trap cross within the patch. Following the deployment of the un-instrumented surface drifter into the patch and a rough determination of the surface drift, we deployed the inside-patch trap array and tracked it for 2 days. Of the trap crosses on each array, four trap tubes were designated for stable isotope analyses. Cretaceous chalk has a unique del- ${ }^{18} \mathrm{O}$ signature relative to modern planktonic carbonates that makes it easy to trace in the water column and it provided us with the means to verify that collected material in the traps originated from the patch. The second set of four trap tubes per drifting array (inside and outside the patches) were designated for microscopic and geochemical analyses. 


\section{WORK COMPLETED}

Our original proposal was for the first cruise to begin during summer of 2001 but due to ship scheduling problems, this was postponed to November 2001. This cruise was done under highly variable weather conditions; weather at the Gulf of Maine site (first patch deployment) was overcast, windy with rain and snow. Due to extremely rough sea-state, work conditions were extremely dangerous (e.g swinging one-ton bags of chalk around the deck); nonetheless, all the chalk was dispersed without incident. The heavy sea state led to the loss of one of the sediment trap drifters (inside-patch trap). Nonetheless, all the other optical and physical drifter studies were completed successfully.

Significantly milder sea-states prevailed at the slope station (second patch station) which allowed much safer working conditions and faster chalk deployment. The patch was deployed under blue skies, timed between two high-energy weather systems. One pre-chalk survey and five post-chalk surveys were accomplished at this station, along with high-resolution tracking of the hydrodrifter, Lagrangian and sediment-trap drifters. The inside-patch trap drifter best tracked the major chalk layer (concentrated between 5-20m depth, within a weak, but well-defined mixed layer that developed during the experiment). Measured mean flow relative to the drifting trap surfaces was low, $<2.5 \mathrm{~cm} / \mathrm{sec}$, although the standard deviations were much higher and displayed a distinctive semidiurnal tidal signal. All optical data have been worked-up, and maps of the chalk associated with various density horizons have been completed using MatLab. All discrete samples for PIC and sediment trap material have been processed. Due to budget cutbacks, the second cruise was rescheduled for Summer 2003. Planning for that trip is currently underway.

Presently we are preparing zooplankton fecal pellet samples for del ${ }^{18} \mathrm{O}$ analyses. These were obtained from on-board, chalk-feeding experiments with copepods (completed by H. Dam). The objective is to determine if we can obtain a baseline del ${ }^{18} \mathrm{O}$ value for zooplankton fecal pellets produced under controlled chalk-feeding conditions. Additionally, we are using the integrated flow speed and direction data from above the 2001 traps to calculate the expected trajectories of chalk particles based on their incorporation into particle matter of variable sinking rates.

\section{RESULTS}

The results from our November cruise indeed demonstrated the importance of physical processes in controlling the chalk distribution. This was especially true in the first patch in the mid-Gulf of Maine where the chalk was mixed into the top $70 \mathrm{~m}$ almost as fast as it was added to the surface water. While the increase in backscattering was measurable, it rapidly decreased to background levels and was impossible to locate with the Scan-Fish and surface sampling within several hours of deployment. Weather at the second Continental Slope station (2000m depth) was Force 8 for a week prior to our arrival, but as we arrived on station, the wind decreased and surface heating caused increasing stratification. The chalk was dispersed after a pre-chalk survey, and the patch was observed by MODIS-Terra. We were able to define the initial shape of the patch using the surveillance balloon (with real-time video). This was invaluable for designing subsequent sampling strategy as the patch spread along a frontal boundary.

This patch was associated with a well-defined "injection" density and could be found within +/-0.05 sigma-theta units of the original density. The drifter that best followed the patch was the sediment 


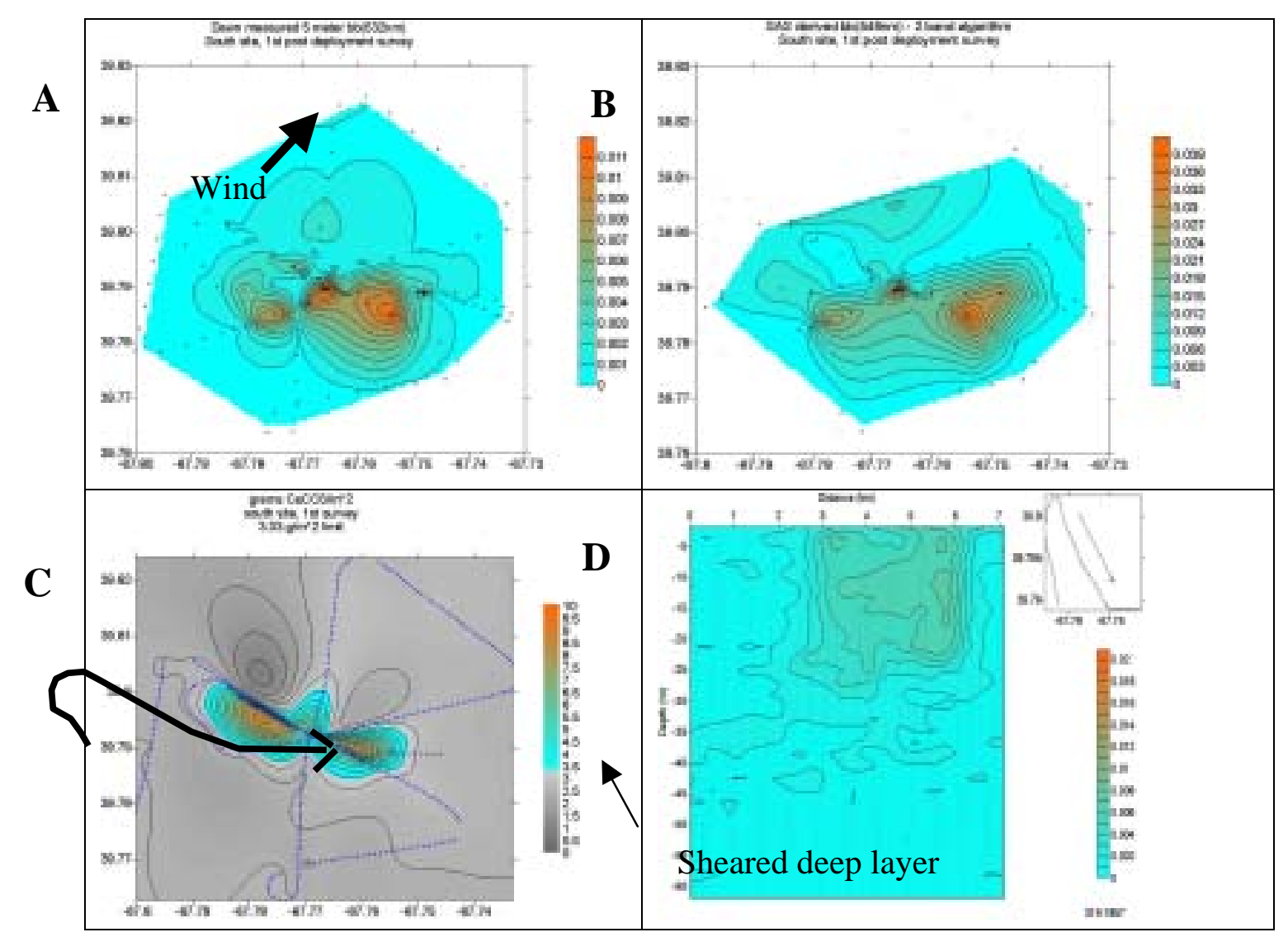

Fig. 1- Southern mesotrophic chalk patch. A) first survey, patch map based on 532nm backscattering at $5 \mathrm{~m}$. B) Patch survey based on above-water SAS radiance measurements, run through the backscattering model of Gordon et al. (1979) to estimate backscattering. The smaller

shape in the survey area in panel $B$ was due to the elimination of sun glint-contaminated measurements from the ships above-water radiance data (i.e. caused by bad solar azimuth angles) C)Patch survey of 60m integrated $\mathrm{CaCO}_{3}$ concentration based on $\mathrm{ECO}-\mathrm{VSF}$ bb measurements from towed scanfish. Backscattering data converted to $\mathrm{CaCO}_{3}$ concentration using laboratory calibrated relationship. Scanfish data were first integrated by depth, then by area for contouring. Grey color represents $\mathrm{CaCO}_{3}$ concentrations at or below background, based on the pre-chalk survey. Arrow designates one vertical section through patch, with section shown in panel $D$. It can be seen that the chalk quickly had mixed to 35m. Comparison of panels $A$ and B show similar patch size and shape,

but bb estimates based on above water radiance were greater than values from $5 \mathrm{~m}$, suggesting preferential chalk concentration in waters $<5 \mathrm{~m}$. Moreover, comparison of surface concentrations integrated to $60 \mathrm{~m}$ values show that the shallow chalk was sheered by the wind to the NW (panel A), and deeper chalk showed a layer at 35-40m sheared to the SE (panel D).

trap drifter, drogued to the top 10m. Dispersion of the chalk between the hydrodrifter, Lagrangian drifters, and sediment trap drifters illustrated the mixed layer shear. We were able to account for all the chalk within the first $6 \mathrm{~h}$ after the patch was dispersed, but the measurable chalk decreased exponentially over time, at a mass-specific rate of $-0.15 \mathrm{~h}^{-1}$. Optical patch definition using light scattering results and above-water radiance measurements were in good agreement (Fig. 1). None of the chalk settled into the sediment traps; similar sinking fluxes of $\mathrm{CaCO}_{3}$ and organic carbon were collected by the inside-patch and outside-patch traps. The total particle mass flux outside the patch 
was slightly higher than that measured inside the patch but the difference was not significant. Trap samples consisted primarily of planktonic foraminifera and pteropod tests as well as crustacean

zooplankton fecal pellets and amorphous organic matter. Stable isotope analyses $\left(\mathrm{d}^{18} \mathrm{O}\right)$ of the trapped detrital material, from which planktonic forams and pteropods were removed, revealed a strong planktonic calcite signature, not the highly depleted value typical of Cretaceous chalk. These results, coupled with the lack of chalk-containing fecal pellets and/or chalk-containing organic aggregates in the traps, indicates that biogenic and/or physical aggregation of chalk particles were not important mechanisms contributing to the fate of the chalk particles during the late-fall experiment. This may change substantially in the upcoming June 2003 chalk experiment in which we expect zooplankton abundance and organic aggregate formation in the upper water column to be significantly higher than in November. This, combined with the minimal chalk grazing by macrozooplankton and measurable grazing by microzooplankton (See Dam \& McManus report), suggests a potential microzooplankton sink for the chalk.

One fascinating result was the observation of a "hole" in the distribution of chromophoric dissolved organic matter (based on continuous measurements of $\mathrm{a}_{\mathrm{g}} 412$ ) in regions of high chalk concentrations. Reduced $\mathrm{a}_{\mathrm{g}} 412$ plus the size spectrum data of the sub-micron particles (as measured with Flow Field Fractionation), suggests in situ adsorption of the cDOM onto the chalk. Such an observation is not without precedent, but the magnitude of this effect was certainly unexpected.

\section{IMPACT/APPLICATIONS}

These experiments are designed to identify the major loss terms of optically-active particles. This is critical for understanding the evolution of the underwater optical field and prediction of underwater visibility on horizontal and vertical spatial scales of 1-10,000 m and 1-100m, respectively, and time scales of hours to several days. The adsorption of chromophoric DOC onto chalk particles has ramifications to the fate of DOC, the largest organic pool in the sea. Overall, the data demonstrate how important physical mixing conditions are to the initiation and retention of a highly reflective coccolithophore bloom. The potential importance of microzooplankton (relative to macrozooplankton) to loss of the chalk was unexpected and has implications to calcite dissolution and turnover in the sea.

\section{TRANSITIONS}

The Chalk-Ex principal investigators have met twice at the University of New Hampshire since the cruise to discuss results. A series of presentations is being planned for the December '02 AGU meeting in San Francisco. We are currently preparing for our summer ' 03 cruise. This will occur during a period of significantly more stratification, and we expect larger biological sinks and lower physical sinks.

\section{RELATED PROJECTS}

Other co-PI's in this project are Dr. A. Plueddemann (Woods Hole Oceanographic Inst.) and Drs. H. Dam and G. McManus (Univ. Connecticut). Dr. J. Goes (Bigelow Laboratory) has worked in this project as well as associated ONR-supported work on virally-mediated production of sub-micron particles. Dr. H. Gordon (U. Miami) and WMB have collaborated in earlier chalk experiments as part of a NASA MODIS contract to derive a remote sensing algorithm for the determination of $\mathrm{CaCO}_{3}$ from space. A DURIP grant, "Upgrading instrumentation to measure light scattering in the sea" was also 
funded as part of this project (co-authored by J. Vaughn, [Univ. New England] and WMB; this equipment was utilized in these experiments.

\section{REFERENCES}

Fernández, E., P. Boyd, P. M. Holligan, and D. S. Harbour. 1993. Production of organic and inorganic carbon within a large scale coccolithophore bloom in the northeast Atlantic Ocean. Mar. Ecol. Prog. Ser. 97: 271-285.

Gordon, D. C., Jr., and A. R. Longhurst. 1979. The environmental aspects of a tidal power project in the upper reaches of the Bay of Fundy. Mar. Pollut. Bull. 10: 38-45.

Knap, A. H. 1993. Bermuda Atlantic time-series study-BATS Method Manual US JGOFS Plann. And Coord. Off., Woods Hole Oceanogr. Inst., Woods Hole, MA. version 3.

Knauer, G. A., J. H. Martin, and K. W. Bruland. 1979. Fluxes of particulate carbon, nitrogen and phosphorus in the upper water column of the northeast Pacific. Deep-Sea Res. 26: 97-108.

\section{PUBLICATIONS ACKNOWLEDGING ONR SUPPORT- LAST 5 YEARS}

\section{W. M. Balch}

Balch, W. M., D. Drapeau, B. Bowler, E. Booth, J. Goes, A. Ashe, and J. Frye. 2002. A multi-year record of optical properties in the Gulf of Maine: I. Spatial and temporal variability. Submitted to Progress in Oceanography.

Broerse, A.T.C., Tyrrell, T., Young, J. R., Poulton, A. J., Merico, A. and W. M. Balch. 2002. The cause of bright waters in the Bering Sea in winter. 2002 Submitted to Cont. and Shelf Research

Vaillancourt, R.D., C.W. Brown, R.R.L. Guillard, W. M. Balch. 2002. Light backscattering by phytoplankton algae and a heterotrophic bacterium measured with a multi-wavelength, fixed-angle backscattering meter. Submitted to J. Geophys. Res..

Balch, W.M., Vaughn, J.M., Novotny, J.F., Drapeau, D.T., Goes, J.I., Lapierre, J.M., Scally, E, Vining, C.L., Ashe, A., and Vaughn, J.M. Jr. 2002. Fundamental changes in light scattering associated with infection of marine bacteria by bacteriophage. Limnology and Oceanography. 47(5): 1554-1561.

Balch, W. M., D. Drapeau, J. Fritz, B. Bowler, and J. Nolan. 2001. Optical backscattering in the Arabian Sea- Continuous underway measurements of particulate inorganic and organic carbon. Deep Sea Res. I. 48: 2423-2452.

H. R. Gordon,1 G. C. Boynton, W. M. Balch, S. B. Groom, D. S. Harbour, and T. J. Smyth. 2001. Retrieval of Coccolithophore Calcite Concentration from SeaWiFS Imagery. Geophysical Research Letters, 28: 1587-1590.

Balch, W.M., Vaughn, J., Novotny, J., D. T. Drapeau, R.D. Vaillancourt, J. Lapierre, and A. Ashe, 2000. Light scattering by viral suspensions. Limnology and Oceanography. 45:492-498. 
Vaillancourt, R. D. and W. M. Balch. 2000. Size distribution of coastal sub-micron particles determined by flow, field flow fractionation. Limnology and Oceanography. 45: 485-492.

Balch, W. M., D. Drapeau, and J. Fritz. 2000. Monsoonal forcing of calcification in the Arabian Sea Deep Sea Research II, 47: 1301-1333.

Milliman, J., P.J. Troy, W. Balch, A.K. Adams, Y.-H. Li, and F.T. MacKenzie . 1999. Biologicallymediated dissolution of calcium carbonate above the chemical lysocline? Deep-Sea Res. I. 46: 16531669.

Balch, William M., David T. Drapeau, Terry L. Cucci, and Robert D. Vaillancourt, Katherine A. Kilpatrick, Jennifer J. Fritz. 1999. Optical backscattering by calcifying algae-Separating the contribution by particulate inorganic and organic carbon fractions J. Geophys. Res. 104: 1541-1558.

Voss, K., W. M. Balch, and K. A. Kilpatrick. 1998. Scattering and attenuation properties of Emiliania huxleyi cells and their detached coccoliths. Limnol. Oceanogr. 43: 870-876.

Balch, W. M., B. Bowler, and C.F. Byrne. 1997. Sea surface temperature gradients, baroclinicity, and vegetation gradients in the sea. J. Plank. Res. 19: 1829-1858.

Balch, W. M., J. J. Fritz, and E. Fernandez. 1996. Decoupling of calcification and photosynthesis in the coccolithophore Emiliania huxleyi under steady-state light-limited growth. Marine Ecology Progress Series. 142: 87-97.

Bidigare, R. R. , M. Latasa, Z. Johnson, R. T. Barber, C. C. Trees, and W. M. Balch. 1997. Observations of a Synechococcus-dominated cyclonic eddy in open-oceanic waters of the Arabian Sea. Society of Photo-Optical Instrumentation Engineers, Vol. 2963. pp. 260-265. 